\title{
The Neandertal lower right deciduous second molar from Trou de l'Abîme at Couvin, Belgium
}

\author{
Michel Toussaint ${ }^{\mathrm{a}, *}$, Anthony J. Olejniczak ${ }^{\mathrm{b}}$, Sireen El Zaatari ${ }^{\mathrm{b}}$, Pierre Cattelain ${ }^{\mathrm{c}}$, Damien Flas ${ }^{\mathrm{d}}$, \\ Claire Letourneux ${ }^{\mathrm{b}}$, Stéphane Pirson ${ }^{\mathrm{e}}$ \\ a Direction de l'Archéologie, Service Public de Wallonie, 1 rue des Brigades d'Irlande, B-5100 Namur, Belgium \\ ${ }^{\mathrm{b}}$ Department of Human Evolution, Max Planck Institute for Evolutionary Anthropology, Deutscher Platz 6, D-04103 Leipzig, Germany \\ ${ }^{\mathrm{c}}$ Musée du Malgré-Tout and CEDARC, rue de la Gare, 28, B-5670 Treignes, Belgium \\ d Musées royaux d'Art et d'Histoire, parc du Cinquantenaire, B-1000 Brussels, Belgium

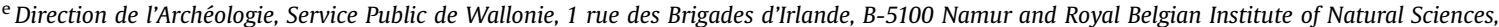 \\ 29 rue Vautier, B-1000 Brussels, Belgium
}

\section{A R T I C L E I N F O}

\section{Article history:}

Received 13 June 2008

Accepted 11 August 2009

\section{Keywords:}

Middle Palaeolithic

Enamel thickness

Neandertals

Couvin

Deciduous lower molar

\begin{abstract}
A B S T R A C T
A human lower right deciduous second molar was discovered in 1984 at the entrance of Trou de l'Abîme at Couvin (Belgium). In subsequent years the interpretation of this fossil remained difficult for various reasons: (1) the lack of taxonomically diagnostic elements which would support its attribution to either Homo (sapiens) neanderthalensis or H. s. sapiens; (2) the absence of any reliable chronostratigraphic interpretation of the sedimentary sequence of the site; (3) the contradiction between archaeological interpretations, which attributed the lithic industry to a transitional facies between the Middle and Early Upper Palaeolithic, and the radiocarbon date of 46,820 $\pm 3,290 \mathrm{BP}$ obtained from animal bone remains associated with the tooth and the flint tools.

Thanks to recent progress regarding these three aspects, the tooth from Trou de l'Abîme may now be studied in detail. Analyses of the morphology and enamel thickness of the fossil yielded diagnostic characters consistent with an attribution to Neandertals. Re-examination of the lithic industry of Couvin shows that it corresponds to the late Middle Palaeolithic rather than a transitional facies. Furthermore, a new analysis of the site stratigraphy indicates that the unit situated above the archaeological layer in which the tooth was found is probably a palaeosol of brown soil type. Comparison with the regional cave sequences as well as with the reference sequence from the Belgian loess belt tends to show that the most recent palaeosol of this type is dated between 42,000 and $40,000 \mathrm{BP}$. This is consistent with both a recently obtained AMS result at $44,500 \mathrm{BP}$ and the published conventional date.
\end{abstract}

(c) 2009 Elsevier Ltd. All rights reserved.

\section{Introduction}

The excavation carried out from 1984 to 1987 in front of the main entrance of Trou de l'Abîme, a cave situated in the town of Couvin, in Belgium, yielded a human deciduous right lower second molar. This tooth was the first palaeoanthropological discovery older than the late glacial found in Belgium since 1895 (Toussaint and Pirson, 2006). Furthermore, the tooth was found in the course of a modern multidisciplinary excavation programme, and the associated archaeological material was, at the time of the discovery, interpreted as a transitional facies between the Middle and Upper

\footnotetext{
* Corresponding author.

E-mail addresses: michel.toussaint@spw.wallonie.be, mtoussaint1866@hotmail. com (M. Toussaint).
}

Palaeolithic ("facies of Couvin"). This lithic material would therefore have been approximately contemporaneous with other transitional technocomplexes such as the Châtelperronian and LincombianRanisian-Jerzmanowician (LRJ). As a consequence, a thorough study of the human fossil from Couvin after its discovery would have been particularly important since it would have been considered in the broader context of the replacement of Neandertals by anatomically modern humans in Europe (e.g., Trinkaus, 2007). However, in the following years, the interpretation of the fossil remained difficult. In the 1980s, an isolated deciduous molar, particularly one exhibiting a slightly worn occlusal face, was not considered sufficiently diagnostic to allow a distinction between Homo (sapiens) neanderthalensis and H. s. sapiens (Tillier, 1990). Additionally, there was a discrepancy between the supposed transitional nature of the lithic industry and the single radiocarbon date (c. 46,000 BP). The description of the fossil was thus postponed. 
Recently, progress has been made in the morphological study of Neandertal teeth, both permanent and deciduous (e.g., Bailey, 2002; Bailey and Hublin, 2006), which supports the main objective of the present paper, that is, the first detailed analysis of the Couvin tooth, its morphology, enamel thickness, and assessment of its taxonomic position. Until now, the discovery has only been mentioned a few times, either in the discoverers' field report (Cattelain et al., 1986; Ulrix-Closset et al., 1988), in general anthropology papers (Tillier, 1990), or in regional accounts (Toussaint and Pirson, 2006), but without any anthropological description.

The second objective of the current study is to re-examine the context of the tooth. A few years after the excavations, doubts had been expressed about the transitional nature of the Couvin lithic industry (Ulrix-Closset, 1990). To assess this matter, we present a new analysis of this industry, based on recent progress in the understanding of transitional industries (e.g., Flas, 2008). This archaeological analysis was conducted within the larger context of a rigorous reinterpretation of the stratigraphy and chronology of the site, building upon recent research on cave entrance sequences in Belgium (Pirson, 2007). Should the transitional nature of the lithic industry of Couvin be substantiated by further analysis, the tooth would participate in the debate about human fossils from transitional cultures; in this regard, the evaluation of its taxonomic status would be of the greatest importance. Alternatively, should the industry prove to be nothing more than from the late Middle Palaeolithic, the tooth would simply be a new Neandertal find, according to the equation, apparently legitimate in northwest Europe before $40,000 \mathrm{BP}$, which suggests that the Middle Palaeolithic and Neandertals are related.

\section{Materials and methods}

\section{Trou de l'Abîme}

Trou de l'Abîme is a cave located on the right bank of the Eau Noire River, in the centre of the town of Couvin (Belgium). The site comprises a large cave with two levels, the entrance of the upper level being on the west face of an Eifelian limestone cliff, as well as a vast terrace forming a rockshelter $50 \mathrm{~m}$ long and $5 \mathrm{~m}$ deep (Fig. 1).

The cave entrance was excavated on several occasions at the turn of the 19th century (Lohest and Braconier, 1887-1888; Maillieux, 1903). The lithic and faunal remains of these first excavations seem to be lost. In 1905, four trenches were cut in the terrace. Three of them produced only backfill, the fourth yielded in situ deposits and sediments reworked from the cave; the archaeological and palaeontological material come from these reworked sediments (de Loë, 1906). Finally, in 1984-1987, three test pits were cut in the cave terrace, of which two yielded only medieval and modern backfill (Cattelain et al., 1986; Ulrix-Closset et al., 1988). The third (A), just a few $\mathrm{m}^{2}$, is where the tooth (G6-0083) was found, on October 5th, 1984, associated with Palaeolithic stone artefacts and Pleistocene fauna. All of this material is housed at the "Musée du Malgré-Tout," at Treignes (Belgium).

The most complete stratigraphic sequence from the 1984-1987 excavations in Couvin has been recorded in trench A (Fig. 2; UlrixClosset et al., 1988; Gullentops, unpublished field description):

- VIII to VI: humus; modern and medieval backfill;

- V: orange clayey silt with a few limestone blocks;

- IV: orange clayey silt with large limestone blocks. The sediment presents a structure ranging from clast-supported to openwork;

- III: red-brown silty clay with a strong prismatic structure; some limestone blocks;
- II: yellow-green clayey silt with red spots; a few limestone blocks; rich in lithic and faunal remains;

- Ia: thin layer of yellow clayey silt, rich in calcite fragments;

- Ib: yellow clayey silt with large limestone blocks; the sediment presents a clast-supported structure.

The human tooth was found at the bottom of layer II, just above the boundary with layer Ia, in square G6, at a depth of about $2 \mathrm{~m}$ below the present surface of the terrace $(x=67 \mathrm{~cm} ; y=93 \mathrm{~cm}$; $\mathrm{z}=244.5 \mathrm{~cm}$ below the reference zero point).

Some parallels can be drawn between this modern stratigraphic record and those from the first excavations by $\mathrm{M}$. Lohest and I. Braconier (1887-1888) and E. Maillieux (1903), conducted near the recently excavated trench A. On the other hand, A. de Loë (1906) transmitted no stratigraphic information with his archaeological and palaeontological findings, which come from the backfill material of previous work.

\section{Anthropological study}

The following description of the tooth focuses on diagnostic morphological features of Neandertal teeth, in accordance with recent dental anthropological studies (notably by Bailey [2002] and Bailey and Hublin [2006]).

Bivariate biometric comparisons were conducted from the mesiodistal and buccolingual diameters of the crown to try to clarify the taxonomic position of the tooth. The tooth is compared to a sample of similar specimens from different periods including both Neandertals and anatomically modern humans (Table 1 ). Only teeth belonging to individuals within the limits of the developmental age range of the Couvin tooth were used. The bivariate comparisons make use of the well-known technique of equiprobable ellipses (Defrise-Gussenhoven, 1955); 95\% confidence ellipses were plotted using the statistical software package PAST (PAlaeontological STatistics, ver. 1.77, 2008; Hammer et al., 2001).

Studies of flat-plane (bite-wing) radiographs have demonstrated that Neandertals are characterized by thinner molar enamel than modern humans (e.g., Smith and Zilberman, 1994). Recent three-dimensional microtomographic studies have confirmed that Neandertal molar enamel is absolutely and relatively (size-scaled) thinner than that of modern humans (Macchiarelli et al., 2006; Olejniczak et al., 2008). The Couvin deciduous molar is worn, preventing measurement of whole crown enamel thickness following traditional 3D techniques (Kono, 2004; Tafforeau, 2004; Olejniczak, 2006). Previous studies have shown, however, that the lateral aspect of enamel thickness (i.e., enamel on the lateral walls of a tooth, not in the occlusal basin) is effective at separating taxa (Schwartz, 2000; Olejniczak and Grine, 2005).

In order to assess whether the enamel is thinner in the Couvin specimen than in modern humans, we prepared microtomographic image stacks of the Couvin deciduous molar and compared the lateral aspect of enamel thickness in 3D to that of two modern humans, three Neandertal individuals (Engis 2, Scladina SCLA 4A13, and La Chaise), and four Neolithic Homo sapiens sapiens individuals from the Belgian Meuse Basin. Each image stack was modified such that all images were parallel to the basal plane (an approximation of the best-fit plane through the cervix of the tooth; see also Kono, 2004; Olejniczak, 2006). All images apical to this basal plane were eliminated, thereby removing any images containing tooth root. The image stack was then scrolled until the lowest point of enamel in the occlusal basin was discovered, and all images occlusal to this plane were eliminated. This technique creates an image stack showing only the centre region of the tooth crown, with the occlusal surface removed (thereby removing any worn regions) and with the root removed. That is to say, only the 

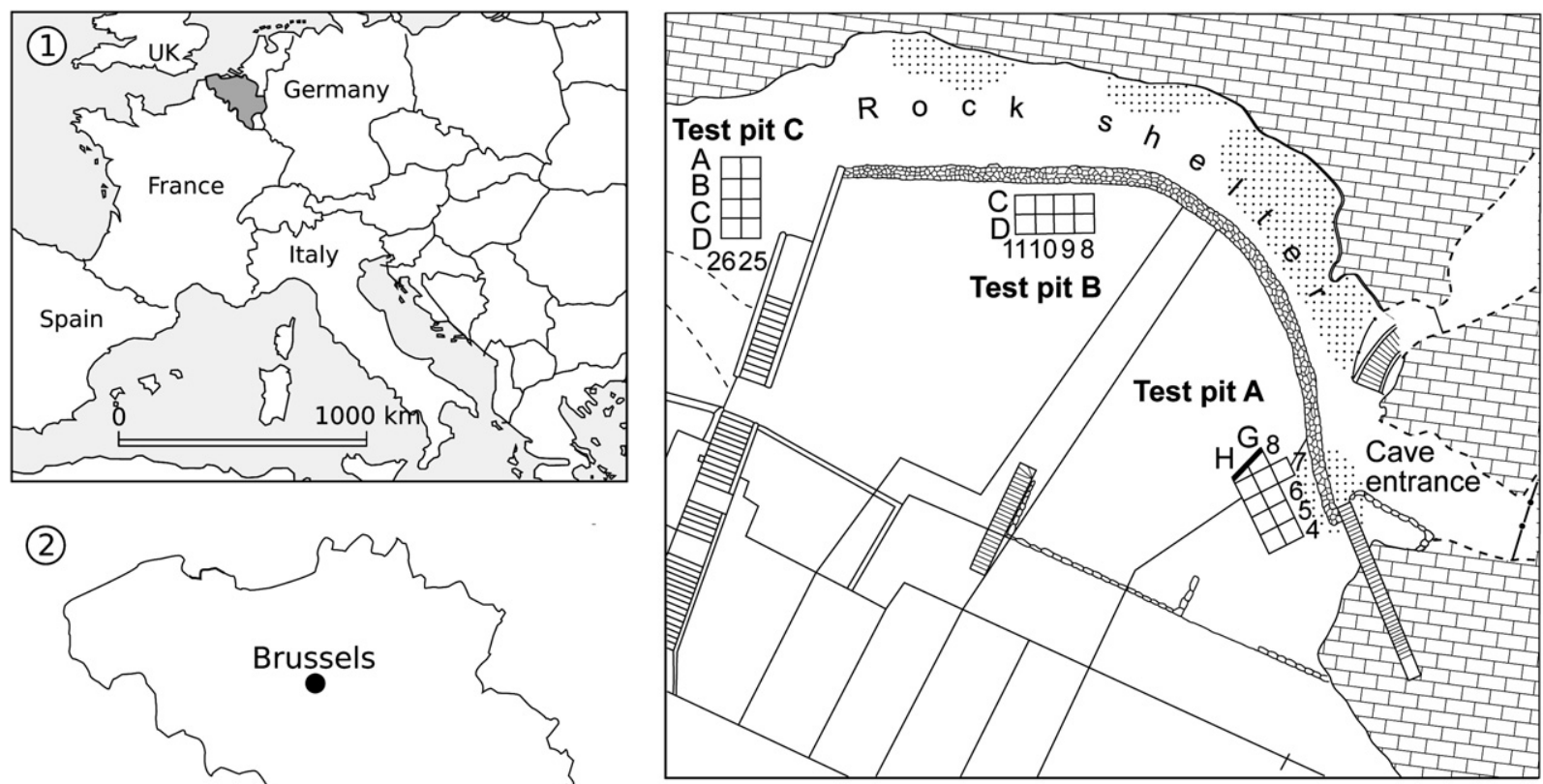

(2)
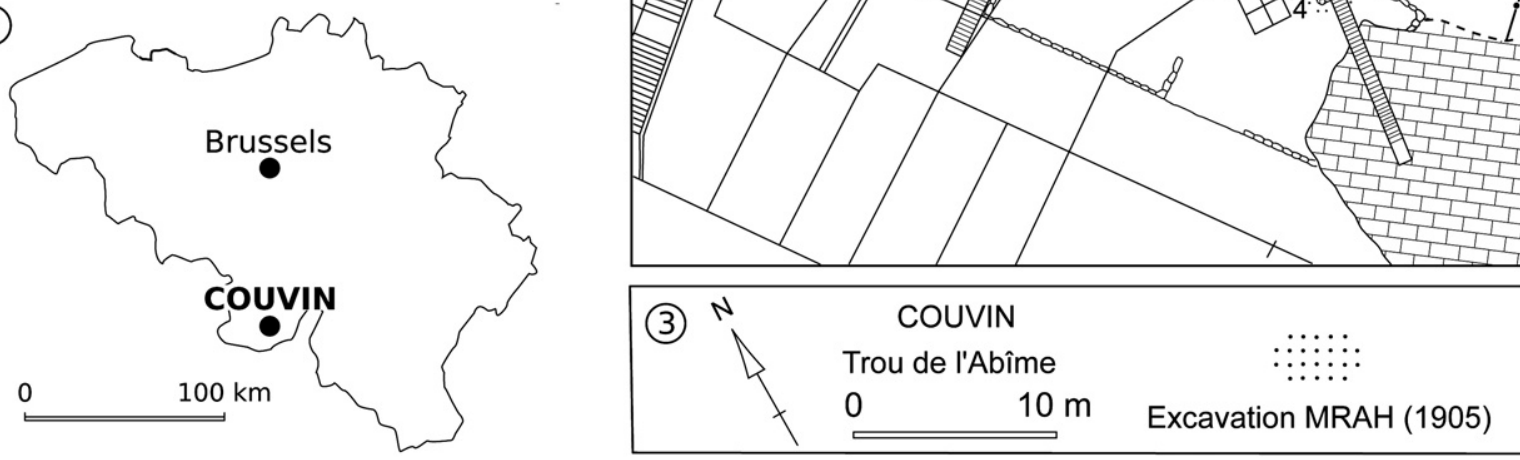

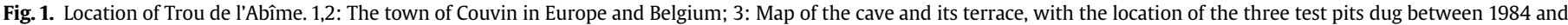
1987 (from Ulrix-Closset et al., 1988). MRAH = "Musées royaux d'Art et d'Histoire."

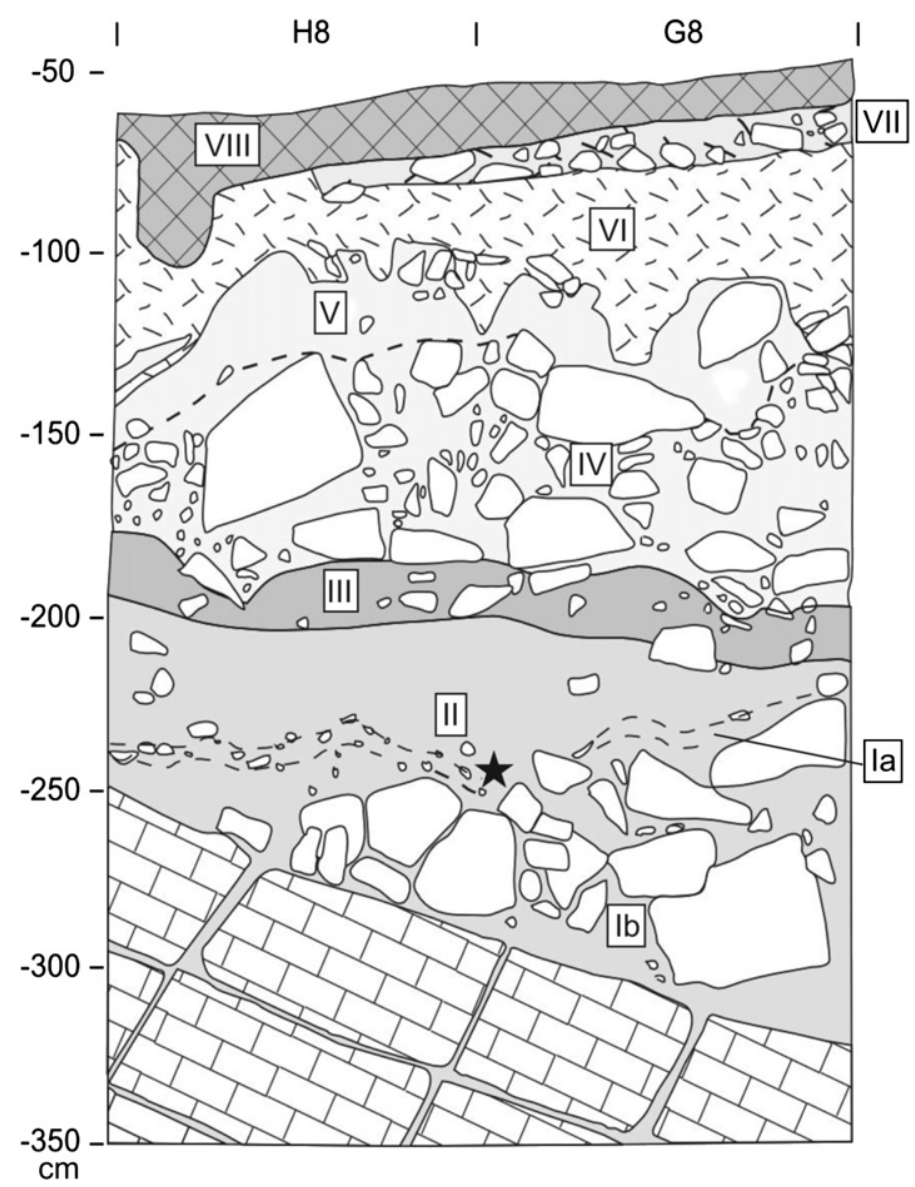

Fig. 2. Trou de l'Abîme: stratigraphic sequence of test pit A, north section, with the location of the human deciduous molar (after Ulrix-Closset et al., 1988). 
Table 1

Mesiodistal (MD) and buccolingual (BL) mean diameters of $d_{2} \mathrm{~s}$, in mm.

\begin{tabular}{|c|c|c|c|}
\hline & & MD & $\mathrm{BL}$ \\
\hline Couvin & & 10.0 & 8.7 \\
\hline \multirow[t]{3}{*}{ Preneandertal and Early Neandertals } & Number & 11 & 11 \\
\hline & Mean & 10.764 & 9.573 \\
\hline & Standard deviation & 0.15 & 0.132 \\
\hline \multirow[t]{3}{*}{ Classical Neandertals } & Number & 32 & 32 \\
\hline & Mean & 10.266 & 9.278 \\
\hline & Standard deviation & 0.1 & 0.079 \\
\hline \multirow[t]{3}{*}{ Upper Palaeolithic H. s. sapiens } & Number & 19 & 20 \\
\hline & Mean & 10.737 & 9.465 \\
\hline & Standard deviation & 0.138 & 0.138 \\
\hline \multirow[t]{3}{*}{ Belgian Neolithic } & Number & 29 & 29 \\
\hline & Mean & 10.128 & 9.017 \\
\hline & Standard deviation & 0.09 & 0.07 \\
\hline \multirow[t]{3}{*}{ Belgian Middle Ages } & Number & 20 & 20 \\
\hline & Mean & 9.980 & 8.685 \\
\hline & Standard deviation & 0.11 & 0.1 \\
\hline \multirow[t]{3}{*}{ XXth century native S. African } & Number & 22 & 22 \\
\hline & Mean & 10.168 & 9.054 \\
\hline & Standard deviation & 0.12 & 0.1 \\
\hline \multirow[t]{3}{*}{ Modern Humans } & Number & 71 & 71 \\
\hline & Mean & 10.098 & 8.935 \\
\hline & Standard deviation & 0.06 & 0.05 \\
\hline
\end{tabular}

lateral aspect of enamel remained, as did the dentine core of the tooth. From this point, standard enamel thickness measurements were recorded (following Kono [2004], Tafforeau [2004], and Olejniczak [2006]). These measurements include: the volume of lateral enamel (cubic $\mathrm{mm}$ ); the volume of dentine contained within the lateral enamel (cubic $\mathrm{mm}$ ); the surface area of the enameldentine junction (EDJ) contained within the lateral enamel (square $\mathrm{mm}$ ); the average enamel thickness of lateral enamel $(\mathrm{mm}$; this measurement is calculated as the volume of lateral enamel, divided by the surface area of the EDJ, yielding the average straight-line distance between the EDJ and outer enamel surface); the lateral relative enamel thickness index (scale-free; which is calculated as average enamel thickness divided by the cubic root of dentine volume, yielding a measure of enamel thickness that is effectively scaled for tooth size. Lower values of the relative enamel thickness correspond to thinner enamel, and higher values indicate thicker enamel).

Dental microwear texture analysis, a combination of confocal microscopy and scale-sensitive fractal analysis (Scott et al., 2006; El Zaatari, 2007), was used to study the occlusal dental microwear of the Couvin molar to gain insights into the dietary habits of this individual. Molds and scans of the Couvin molar were made using already established procedures (Teaford and Oyen, 1989; see technical details and results in Supplementary Online Materials [SOM]).

\section{Contextual re-evaluation}

The flint material associated with the tooth has been re-examined by the authors on the basis of the current typology and, most notably, the distinction between Middle Palaeolithic leaf points and those from proven transitional industries, such as the Jerzmanowice points (Flas, 2008).

A new chronostratigraphic interpretation of the sedimentary sequence from the cave terrace is presented. It is based on recent progress in the understanding of cave entrance stratigraphic sequences in Belgium, essentially those of Walou and Scladina, as well as on the comparison between these sequences and those of the Belgian loess belt (Pirson et al., 2006, 2008; Pirson, 2007).
Macrofaunal data are available from several studies (Lohest and Braconier, 1887-1888; Maillieux, 1903; Cordy, 1984; Cattelain et al., 1986). On the other hand, microfaunal data remain unpublished, but a palaeoenvironmental interpretation is available (Cordy, quoted in Cattelain et al., 1986). A re-examination of the 1984-1987 faunal material was conducted in the course of this study.

Three ${ }^{14} \mathrm{C}$ dates are available in the literature: one conventional date from the recent excavations (Lv-1559; Cattelain et al., 1986) and two dates from the 1905 excavation (one conventional [Lv-720; Gilot, 1984] and one AMS [OxA-2452; Vrielynck, 1999]). During the recent re-examination of the Couvin material a new AMS date was obtained from a single horse tooth unearthed from the archaeological layer (GrA-40444).

\section{Results}

\section{Palaeoanthropology}

Description of the deciduous molar. The lower right deciduous second molar found at Couvin is a fully formed crown that lost its root, probably as a result of some taphonomic activity. It is attached to a small piece of irregular breccia, $28.5 \times 20.5 \mathrm{~mm}$ and $9.5 \mathrm{~mm}$ thick. No pathological conditions are visible. The crown is slightly worn; all the cusps are blunt and present millimetre-scale pools of exposed dentine. The wear is between stages 3 and 4 of Molnar (1971). The crown is affected by some postmortem cracks, mainly vertical, on the occlusal surface and the four lateral faces. The enamel is partially damaged along the cervix. The age of the individual to whom the Couvin $\mathrm{dm}_{2}$ belonged was most probably around 5 or 6 years old (see SOM).

The crown exhibits a complex occlusal morphology (Fig. 3). It possesses the four major cusps of lower molars (the protoconid, metaconid, hypoconid, and entoconid) and also a hypoconulid and a cusp 6 (C6, tuberculum sextum). The cusp tips are internally compressed. The occlusal plane is not horizontal, the two mesial cusps being slightly higher.

The mesial marginal ridge, which joins the metaconid and protoconid, forming the mesial border of the occlusal face, is large, continuous, and blunt. On this ridge and near the mid-crown longitudinal axis of the tooth is a very small mesial marginal accessory tubercle (mesioconulid; Grine, 1984: 46). The anterior fovea has the shape of a narrow and shallow groove, like a comma, with a transverse anterior component and a nearly sagittal posterior one, which ultimately emerges into the central fovea.

The essential crest of the protoconid is well marked and transverse. It meets and joins a tiny accessory excrescence extending from the mesial portion of the metaconid, thus forming the mid-trigonid crest (MTC) and the distal border of the anterior fovea. The MTC is not totally continuous, being partly interrupted by the emergence of the anterior fovea into the central fovea, as observed on other Neandertal $\mathrm{dm}_{2}$ s such as that from La Chaise (Macchiarelli et al., 2006). The protoconid lacks a true protostylid (as defined by the ASUDAS; Turner et al., 1991: 24). The metaconid has two essential crests which run into the central fovea (i.e., a central one starting at the middle of the cuspid and a distal one along the distal slope [Fig. 3: $\mathrm{n}^{\circ} 1$ and 2]).

Between the metaconid and the entoconid there is a faint accessory cuspulid which has its own essential crest (Fig. 3: $\mathrm{n}^{\circ} 3$ ); however, this cuspulid is neither wedge-shaped nor separated from the metaconid and entoconid by distinct fissures, as a typical cusp 7 (C7) or tuberculum intermedium or metaconulid would be. It may be referred to as a post-metaconulid (Grine, 1984) or pre-entoconulid/entostylid as it is close to the blunt tip of the entoconid (Scott and Turner, 1997: 52).

The entoconid exhibits two essential crests that emanate towards the centre of the central fovea (Fig. 3: $n^{\circ} 4$ and 5). The 
(1)
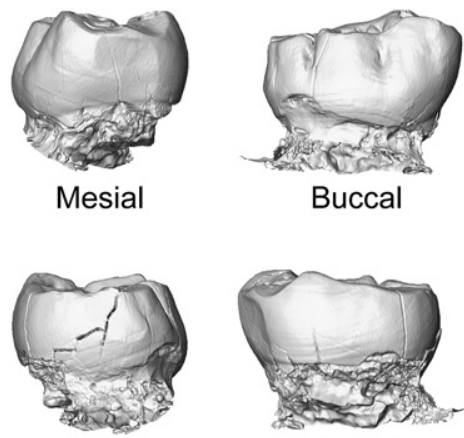

Distal
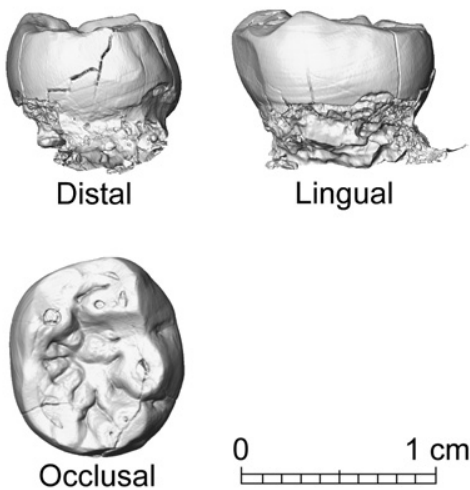

0

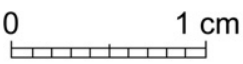

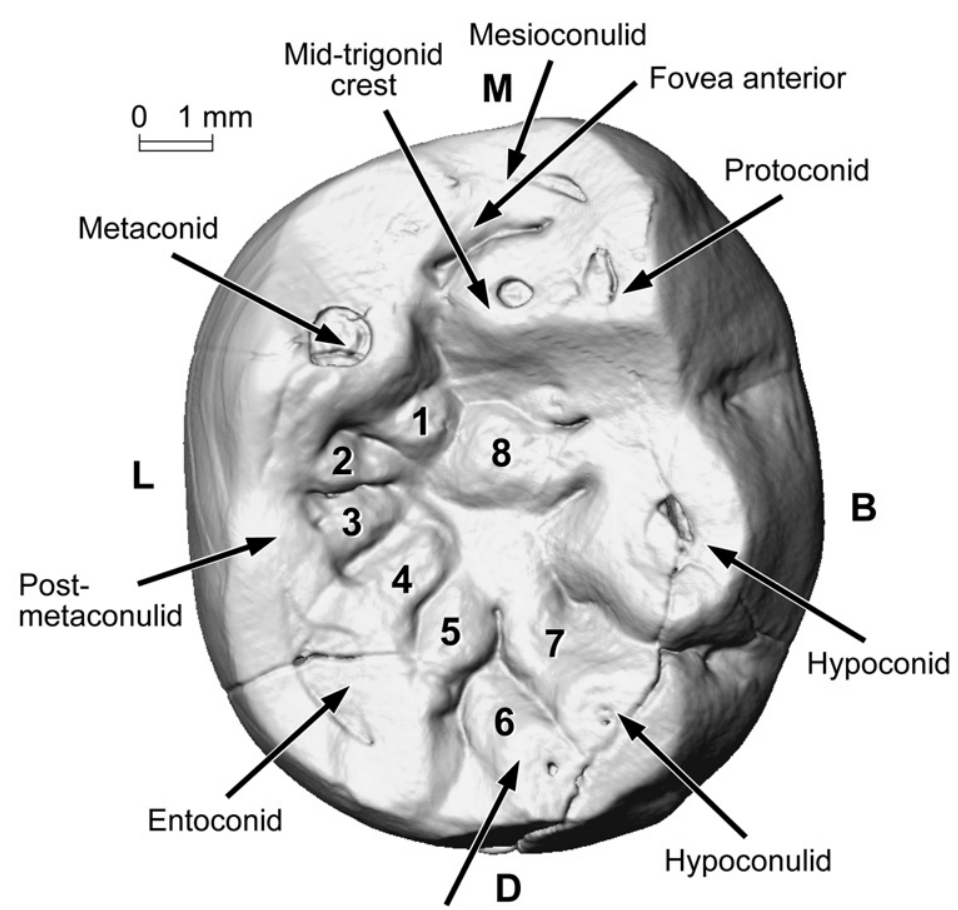

Tuberculum sextum

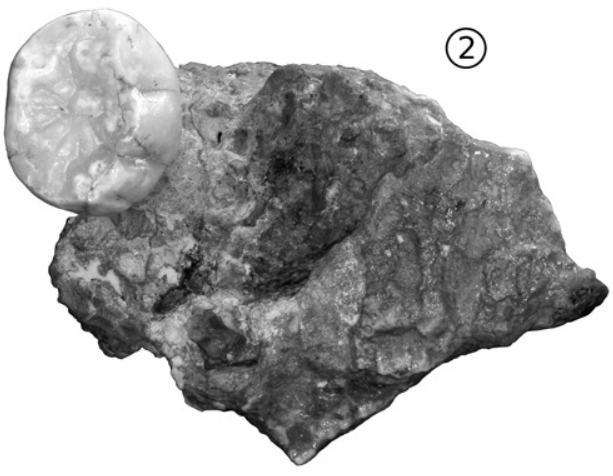

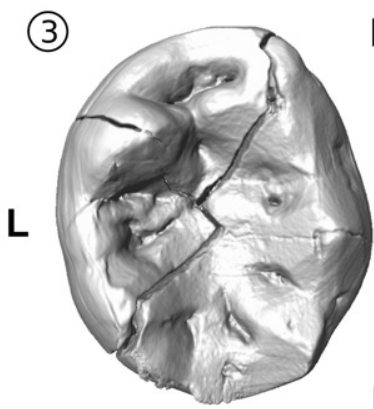

Engis 2

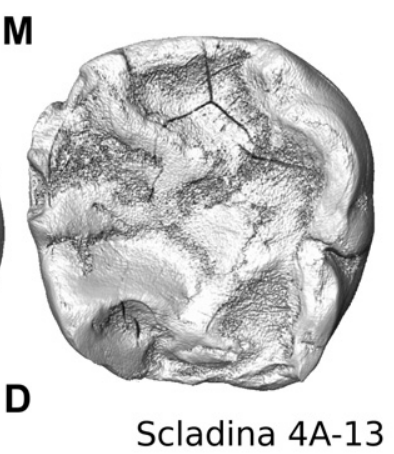

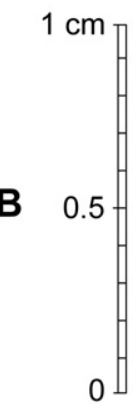

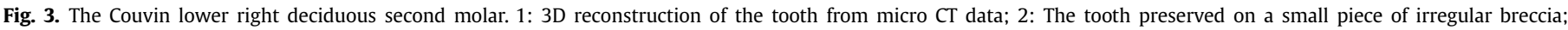
3: Comparison with two Neandertal lower right deciduous second molars, Engis 2 and Scladina SCLA 4A-13.

hypoconid is well defined and separated from the adjacent protoconid and hypoconulid by marked grooves. It is blunt and even slightly concave. It has two essential crests. The hypoconulid is separated distolingualy from another accessory cuspulid, or C6, by a shallow fissure. Cusp 5 is large, at grade 4 of the Arizona State University Dental Anthropology System (ASUDAS; Turner et al., 1991: 24). Cusp 6 is at grade 2 of ASUDAS as it is slightly smaller than cusp 5. Both $\mathrm{C} 6$ and the hypoconulid have a well marked essential crest (Fig. 3: $\mathrm{n}^{\circ} 6$ and 7).

The central fovea is spacious and exhibits numerous enamel "wrinkles" as defined by Weidenreich (1937) and described above as essential crests. The slightly developed median ridulation of the metaconid joins the well developed median essential crest of the hypoconid (Fig. 3), thus forming a somewhat Y-shaped pattern, but without any 'deflecting wrinkle' (sensu Weidenreich, 1937). The crown does not exhibit a clear fovea posteriorly.

The buccal surface of the crown runs obliquely from top to bottom inwardly, then is strongly convex near the cervix. Two vertical features, the mesiobuccal and distobuccal grooves, separate this surface into three areas corresponding to the buccal faces of the protoconid, the hypoconid, and the hypoconulid. These grooves are large, deep, and terminate near the middle of the crown height. The buccal surface of the protoconid lacks a true protostylid; this structure is, at most, minimally expressed (ASUDAS degree 1; Turner et al., 1991). The mesial surface exhibits an interproximal wear facet which does not appear to modify the outline of the tooth in occlusal view. This facet has a maximal height of $2.9 \mathrm{~mm}$ and a buccolingual breadth of $3.2 \mathrm{~mm}$. A nearly vertical blunt groove, best perceptible in horizontal light, divides the facet in two parts: an upper-buccal one and a lingual one more developed inferiorly. The lingual surface of the crown is smooth. The distal surface has a faint groove between the hypoconulid and the C6. An interproximal wear facet (height: $2.1 \mathrm{~mm}$; bucco-lingual diameter: $2.6 \mathrm{~mm}$ ) appears below the C6; its inferior and lingual borders make a regular curve and it is buccaly limited by the faint groove. In occlusal view, this facet does not appear to alter the outline of the crown.

The microwear texture analysis shows that the diet of the Couvin specimen consisted of very few hard brittle foods and was composed almost exclusively of tough items, which would be consistent with a diet made up almost exclusively of meat (see details in SOM). 
Taxonomic attribution. According to Bailey and Hublin (2006: $505)$, the primary feature differentiating Neandertal deciduous mandibular molars from those of anatomically modern humans is the prominent crest that connects the mesial cusps (i.e., the mid-trigonid crest or MTC). Macchiarelli et al. (2006) add that such a morphology seems to be associated with a generally more complex enameldentine junction. Other Neandertal features are the possession of an ovoid occlusal outline, internally compressed cusps, and a wide anterior fovea bordered by a well-defined mesial marginal ridge (Bailey and Hublin, 2006). In contrast, Upper Palaeolithic $\mathrm{dm}_{2} \mathrm{~s}$ have a rectangular occlusal outline, with more widely spaced cusps and no continuous mid-trigonid crest. It should be added that at least some immature Neandertal $\mathrm{dm}_{2} \mathrm{~S}$ have a MTC which does not form a complete bridge, like some Upper Palaeolithic $\mathrm{dm}_{2} \mathrm{~S}$ (Bailey and Hublin, 2006). As far as morphology is concerned, the Couvin $\mathrm{dm}_{2}$ closely resembles those of Neandertals. It exhibits a complex occlusal morphology and possesses an ovoid outline, internally compressed cusps, and well defined marginal ridges. An MTC is present, although not continuous.

Another technique classically used to distinguish between taxa is metrical comparisons. The $\mathrm{dm}_{2}$ of Couvin has a mesiodistal (MD) diameter of $10.0 \mathrm{~mm}$ and a buccolingual (BL) diameter of $8.7 \mathrm{~mm}$. Figure 4 compares the Couvin tooth with four other series of teeth (Table 1 and SOM Tables 1 and 2): 1) Preneandertals/Early Neandertals; 2) Classical Neandertals; 3) modern humans of the Palaeolithic (combination of Mousterian from the Middle East and Upper Palaeolithic from Europe); 4) anatomically modern Homo sapiens. Couvin is situated in the central area of the four ellipses (95\%), indicating that the dimensions of its crown do not provide clear taxonomic indication; however, the mean values of the MD and BL dimensions of Neandertals are slightly greater than that of the modern group.

In this study, we present a third and new taxonomic argument which appears effective at separating Neandertal deciduous molars
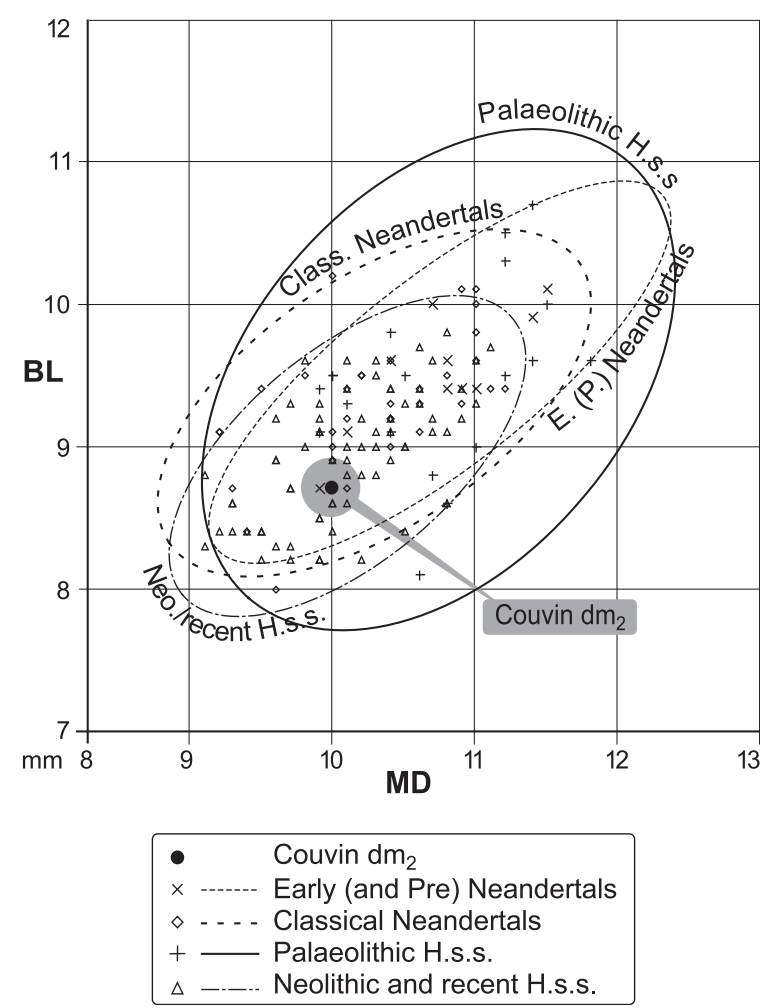

Fig. 4. Graph showing buccolingual/mesiodistal (BL/MD) equiprobable ellipses.
Table 2

Enamel thickness of the Couvin $\mathrm{dm}_{2}$ compared with that of some Neandertals, Neolithics, and Modern humans.

\begin{tabular}{lllllll}
\hline Taxon & Specimen & $\begin{array}{l}\text { Enamel } \\
\text { Volume } \\
\mathrm{mm}^{3}\end{array}$ & $\begin{array}{l}\text { Dentine } \\
\text { Volume } \\
\mathrm{mm}^{3}\end{array}$ & $\begin{array}{l}\text { EDJ } \\
\text { Surface } \\
\text { Area } \\
\mathrm{mm}^{2}\end{array}$ & $\begin{array}{l}\text { Average } \\
\text { Enamel } \\
\text { Thickness } \\
\mathrm{mm}\end{array}$ & $\begin{array}{l}\text { Relative } \\
\text { Enamel } \\
\text { Thickness } \\
\text { scale-free }\end{array}$ \\
\hline $\begin{array}{c}\text { Modern } \\
\text { Human }\end{array}$ & $381-\mathrm{T}-001$ & 37.74 & 160.27 & 86.51 & 0.44 & 8.03 \\
Modern & $382-K-001$ & 40.93 & 187.31 & 88.62 & 0.46 & 8.07 \\
$\quad$ Human & & & & & & \\
Neandertal & Scladina & 22.69 & 174.66 & 104.86 & 0.22 & 3.87 \\
Neandertal & Engis 2 & 34.12 & 187.23 & 121.88 & 0.28 & 4.89 \\
Neandertal & La Chaise & 33.87 & 194.82 & 91.48 & 0.37 & 6.39 \\
& S14-5 & & & & & \\
Neolithic & 2 & 28.23 & 153.68 & 84.49 & 0.33 & 6.24 \\
Neolithic & 3 & 35.22 & 155.68 & 85.15 & 0.41 & 7.69 \\
Neolithic & 4 & 26.68 & 124.20 & 63.66 & 0.42 & 8.40 \\
Neolithic & 5 & 39.16 & 187.00 & 105.32 & 0.37 & 6.50 \\
Unknown & Couvin & 20.99 & 132.84 & 78.21 & 0.27 & 5.26 \\
\hline & & & & & & \\
\hline
\end{tabular}

from those of Neolithic and modern Homo sapiens: the lateral relative enamel thickness index (Table 2; Fig. 5). The relatively thinner enamel of Neandertal permanent molars found in 3D whole-crown studies (Macchiarelli et al., 2006; Olejniczak et al., 2008 ) is also captured, at least in the lateral enamel, in deciduous molars. The Couvin specimen falls squarely within the Neandertal range of lateral relative enamel thickness, with the relatively thinner enamel that is characteristic of Neandertal specimens compared to Homo sapiens.

\section{New interpretation of the $\mathrm{dm}_{2}$ context}

Prehistoric industry. The lithic material of Couvin is composed of two collections: the first, from the 1905 excavations, was found in backfill, therefore without any known stratigraphic provenance (de Loë, 1906); the second (Fig. 6) mainly comes from layer II of the recent 1984-1987 excavations and was strictly associated with the Neandertal tooth which, however, was found at the bottom of the layer (Fig. 7). This material has been interpreted in several ways. The artefacts found in 1905 were first associated with the Solutrean, then the Mousterian, and finally the Protosolutrean (see Cattelain et al., 1986). A quarter of a century ago, they were attributed to a transitional facies between the Middle and Upper Palaeolithic technocomplexes (Otte, 1984; Campbell, 1986). The existence of this transitional facies continued to be widely accepted up to the first years following the new 19841987 excavations; at that time, the lithic material of 1905 and that of 1984-1987 was attributed to a single occupation (e.g., Cattelain et al., 1986; Ulrix-Closset et al., 1988; Otte, 1990). A few years later M. Ulrix-Closset (1990: 142), while studying the two collections, again as a unique set, qualified the initial statements of which she was cosignatory: she stated that the industry of Couvin was a Mousterian from a tradition which used flat retouch, similar in the Belgian context to that of the older Mousterian of the "grotte du Docteur, " and which persisted at the very beginning of the Upper Palaeolithic.

In general, the expression "transitional industry" is used to describe an assemblage mixing features considered characteristic of both the Middle Palaeolithic and the Upper Palaeolithic, and chronologically situated at the boundary between the two periods, from 40,000 to 30,000 B.P. In Northern Europe, including the Belgian Meuse Basin (Spy and Goyet), such a transitional technocomplex has been identified: the Lincombian-Ranisian-Jerzmanowician (LRJ) which is younger than 38,000 B.P. (Jacobi, 2007; Flas, 2008). The LRJ shows a blank production almost exclusively 


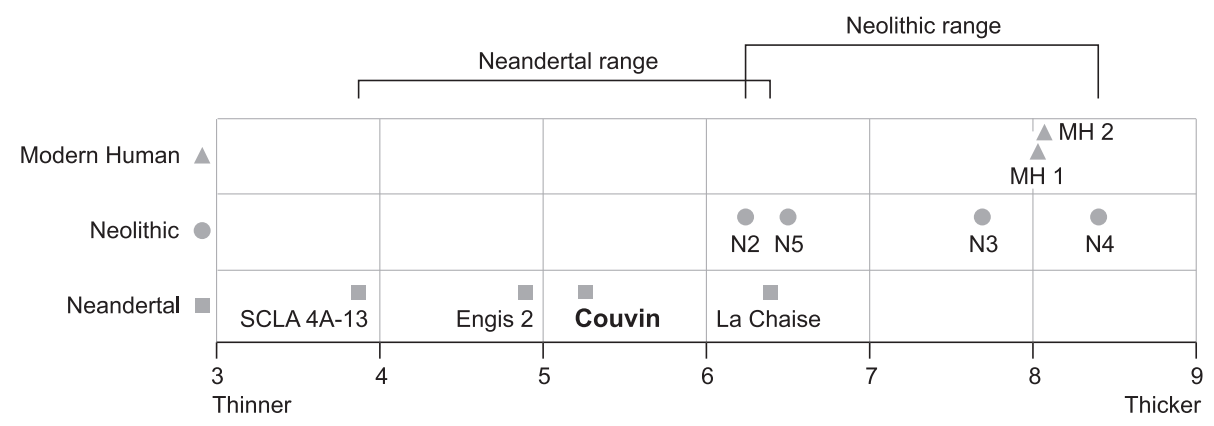

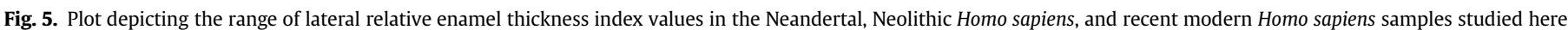
There is little overlap between the Neandertal and Neolithic Homo sapiens samples. The Couvin deciduous molar falls clearly within the range of Neandertals.

from volumetric blade cores, using soft hammer percussion. Most of the leaf points (called "Jerzmanowice points") are thus made of blades like the other tool types that include the usual "Upper Palaeolithic" endscrapers and burins.

Referring back to this concept of transitional industries, a new analysis of the Couvin lithic material was undertaken alongside the study of the deciduous molar. Overall, the typological, technological, and taphonomic features as well as the raw material of the 1905 and 1984-1987 material are similar (see Cattelain et al., 1986; UlrixClosset et al., 1988). However, even if the hypothesis that both collections reflect a single occupation is possible, the lack of stratigraphic data for the 1905 collection, which comes from backdirt, requires caution: its homogeneity is far from being demonstrated, and, even more important, its association with the Neandertal tooth remains uncertain. Therefore, both collections have been studied separately.

The 1905 material is mainly composed of Mousterian sidescrapers (Table 3), either simple, double, convergent, or angled. Other remarkable elements are: a single leaf point, a few side scrapers shaped by bifacial flat retouch, a few flakes from bifacial shaping. There is also a knife quite similar to the Kostenki knife, that is, an artefact with oblique inverse retouch (on the distal extremity) frequently used as a facetted striking platform for narrow and flat removals on the dorsal face. However, this tool has been fashioned on a blade of Middle Palaeolithic technology. In the 1984-1987 material from layer II, the sidescrapers are also the dominant tools, some shaped by bifacial retouch (Fig. $6: \mathrm{n}^{\circ} 2$ and 3 ) that is similar to heavily reduced artefacts coming from other Mousterian assemblages using
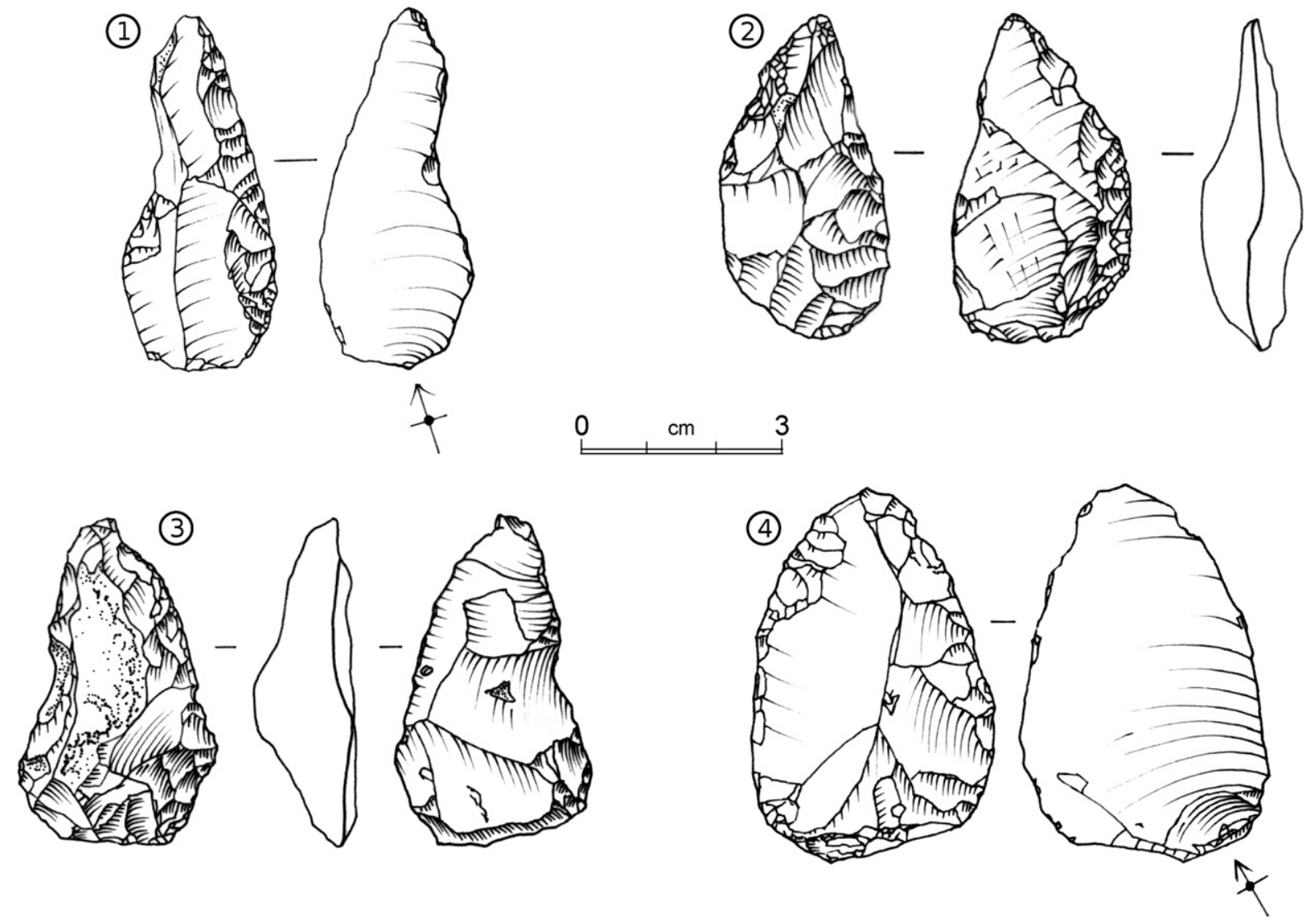

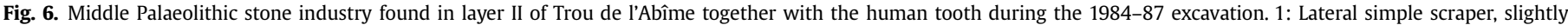

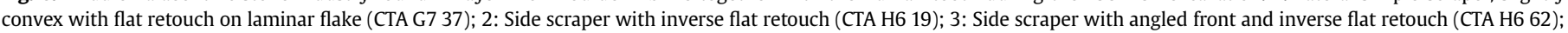
4: Double convergent side scraper (CTA G7 34). 

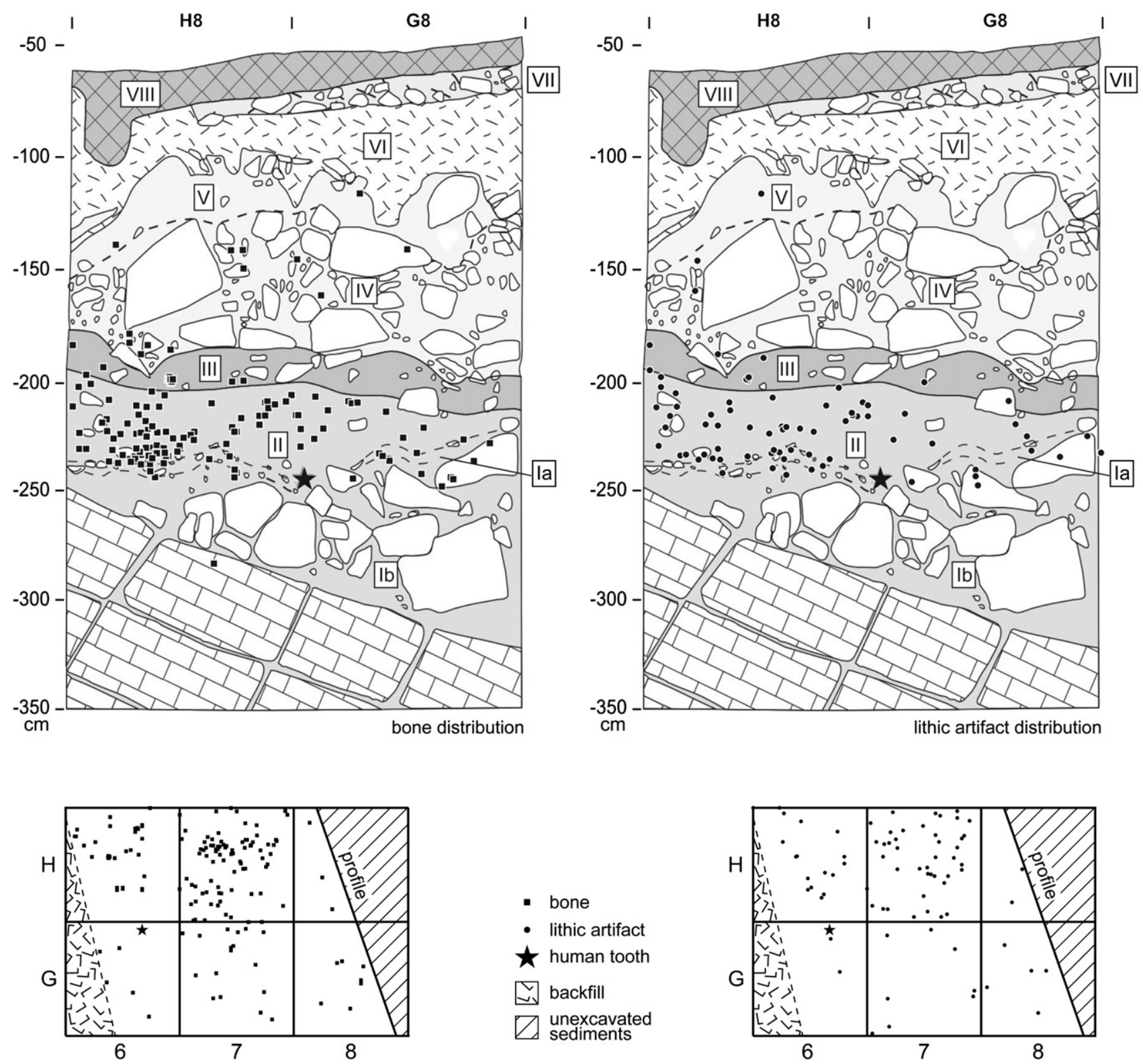

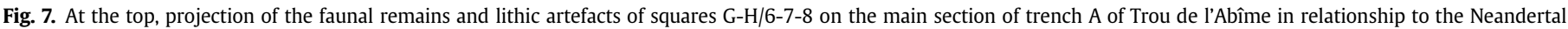
tooth. At the bottom, horizontal distribution of the animal bones and flint artefacts in the same squares.

Table 3

Lithic material from the two available collections from Trou de l'Abîme.

\begin{tabular}{|c|c|c|}
\hline & $\begin{array}{l}\text { Early 20th century } \\
\text { collection }\end{array}$ & 1984-1987 collection \\
\hline Sidescrapers & $\begin{array}{l}26 \text { ( } 4 \text { with bifacial } \\
\text { retouch, } 2 \text { on laminar } \\
\text { blank) }\end{array}$ & $\begin{array}{l}11 \text { ( } 2 \text { with bifacial } \\
\text { retouch, } 1 \text { on laminar } \\
\text { blank) }\end{array}$ \\
\hline Sidescrapers on bifacial piece & 2 & 2 \\
\hline Slightly retouched flakes & 5 & \\
\hline $\begin{array}{l}\text { Flake with extensive ventral } \\
\text { retouch }\end{array}$ & & 1 \\
\hline Leaf point & 1 & \\
\hline Bifacial piece fragments & 2 & \\
\hline Kostenki knife & 1 & \\
\hline Blades and laminar flakes & 1 & 3 \\
\hline $\begin{array}{l}\text { Flakes (including bifacial } \\
\text { reduction and other waste } \\
\text { flakes) }\end{array}$ & 6 & $\begin{array}{l}60+\text { (without the small } \\
\text { chips) }\end{array}$ \\
\hline Flake core fragments & 2 & \\
\hline
\end{tabular}

exotic flint (Slimak, 2008: 278). There is also a single flake with extensive ventral retouch, a few laminar flakes, as well as hundreds of secondary flaking rejects which were found by sieving.

The dominance of sidescrapers and the presence of particular technological features (thick faceted striking platform, hard hammer percussion, well marked bulb) give these assemblages a strong Mousterian character. The "evolved" artefacts once referred to for explaining the transitional nature of the Couvin material are tools shaped by bifacial retouch (leaf points and scrapers) and the most regular among the laminar elements (including the "Kostenki knife"). These artefacts, all coming from the old collection, required reappraisal. The rare blades are just elongated flakes, showing also hard percussion traces and thick faceted platforms. Their presence, as well as that of the "Kostenki knife," is not surprising in a Mousterian assemblage where these elements may be found, even in much older periods of the Middle Palaeolithic (e.g., Révillion and Tuffreau, 1994; Slimak and Lucas, 2005). The presence of flat retouch 
and of a leaf point is not characteristic of a transitional industry either, as already mentioned by Ulrix-Closset (1990), since these features can be found in the older Belgian Middle Palaeolithic (Docteur cave) and in Central Europe Middle Palaeolithic industries (especially the Keilmessergruppen and Blattspitzengruppe: Bosinski, 2001; Jöris, 2003).

In conclusion to our new analysis, the material strictly associated with the Neandertal tooth must be restricted to the artefacts unearthed during the 1984-1987 excavations, which are purely Middle Palaeolithic. However, even if the 1905 and 1984-1987 collections appeared to derive from a single occupation, the Couvin assemblage would remain completely Mousterian and not transitional. The presence of a bifacial leaf point would in that case be diagnostic and the expression "Moustérien à pointe foliacée" ("Mousterian with leaf point") proposed by M. Ulrix-Closset (1990) would therefore be appropriate.

Chronostratigraphy. The main lithological marker from the stratigraphy of Trou de l'Abîme is layer III. The red and compact facies of this unit is evocative of an interstadial palaeosol (brown soil). A photograph of the section taken during the excavation reinforces this interpretation, which is further validated by the unpublished interpretation of layer III by the geologist F. Gullentops: "This does look like an in situ soil with a rather constant thickness of 16-18 cm."

In the well documented pedostratigraphic loess sequence of Middle Belgium, which serves as reference for the regional upper Pleistocene, the most recent brown soil is the "Les Vaux" Soil noticed at Harmignies and Remicourt in the Weichselian middle pleniglacial (Haesaerts et al., 1997). As far as its facies and stratigraphic position are concerned, the "Les Vaux" Soil exhibits close similarities with the Bohunice Soil in Moravia and with the Willendorf Interstadial in Austria (Haesaerts and Teyssandier, 2003). These pedological markers represent a single interstadial event dated between $c$. 42,000 BP and c. 40,000 BP in the Middle Danube Basin and correlated with the Dansgaard-Oeschger Event 12 of the Greenland ice records (Haesaerts, 2004).

In the Belgian Meuse Basin, two cave sequences-Walou and Scladina-have also yielded a similar red-brown pedological horizon within a complex pedostratigraphic sequence which covers all the upper Pleistocene and offers an accurate chronostratigraphic framework (Pirson et al., 2006, 2008; Toussaint and Pirson, 2006; Pirson, 2007). In Walou Cave, the concerned horizon is unit CII-1. It is situated below a Middle Palaeolithic occupation which also yielded a Neandertal tooth. Palynology and magnetic susceptibility both confirm the interstadial nature of this horizon. Taking the lithofacies and the stratigraphic context into account, as well as the radiocarbon and ESR dates available for the overlying and underlying units, parallels with the "Les Vaux" Soil have been proposed. In Scladina cave, unit IB of the terrace is a red-brown horizon interpreted as a palaeosol. The recent re-examination of the chronostratigraphic framework of the site and some new radiocarbon dates indicate that this soil can be positioned between 43,000 BP and 40,000 BP and should again be the "Les Vaux" Soil.

Therefore, according to the comparison with the Belgian loess sequence and with the regional cave records, unit III of "Trou de l'Abîme" is probably a palaeosol which should be at the youngest equivalent with the "Les Vaux" Soil.

Fauna. The fauna collected from the archaeological layer during the excavations conducted in 1887-1888 and 1903 is diverse (e.g., horse, aurochs, hyena, cave bear, boar, red deer, fox, cave lion, wolf, reindeer, ibex, birds, etc.; Lohest and Braconier, 1887-1888; Maillieux, 1903). On the contrary, macrofauna from the 1905 excavations is notably less diverse; according to Cordy (1984), it was characterised by the presence of panther and European wild donkey and the scarcity of reindeer.
The recent re-examination of the 1984-1987 bone collection, found in layer II in close association with the Neandertal tooth and the lithic material (Fig. 7), involved several hundred fragments of faunal bones of which only 25 were identified: horse (16), Bos/Bison (5), bear (1), boar (1), fox (1), and badger (1). The last two species could be intrusive. These results are consistent with the preliminary study of layer II fauna (Cordy quoted in Cattelain et al., 1986; Ulrix-Closset et al., 1988). Three facts suggest an anthropic origin for this collection. The first is the presence of some cutmarks, also noticed in Cordy's preliminary work, indicating defleshing. The second fact is the presence of numerous burnt bones (c. $25 \%$ of the studied material), reported here for the first time. The third is the absence of evidence of carnivore involvement (e.g., no coprolites or gnaw marks on bones). Overall, the macrofaunal assemblage of the recent excavations is similar to that discussed by Lohest and Braconier (1887-1888) and above all by Maillieux (1903). The smaller diversity in species might be related to the limited extension of the 1984-87 excavation trench. On the contrary, the macrofauna from the 1905 excavation appears notably different, which may suggest different stratigraphic origins.

No microfaunal remains are mentioned for the early excavations. Only a brief account of the analysis of the microfauna collected in 1984-1987 and analysed by J.-M. Cordy has been published so far, without any list of species or number of specimens (in Cattelain et al., 1986; Ulrix-Closset et al., 1988). Still, a palaeoenvironmental reconstruction is proposed: the equivalent of layers II and III are interpreted as a probable interstadial. The small mammals unearthed during the 1980's excavations were restudied for the present paper. Unfortunately the material is extremely poor and difficult to stratigraphically associate with certainty.

Radiocarbon dating. The conventional radiometric date obtained from a small set of macrofaunal remains unearthed from layer II during the 1984-1985 excavations yielded a result of $46,820 \pm 3,290 \mathrm{BP}$ (Lv 1559; Cattelain et al., 1986). These macrofaunal remains have been rigorously controlled stratigraphically during the excavation and their association with the archaeological material of layer II is secure. However, this result must be considered with caution as it is a conventional date on several bone fragments, and it was obtained in the 1980s and the result is clearly at the limit of the radiocarbon method. Further validation by AMS dating was thus necessary. In October 2008, a new AMS radiocarbon date was obtained from a single horse tooth collected in 1985 in the archaeological layer. The new result is $44,500+1,100 /-800 \mathrm{BP}$ (GrA-40444). It falls within the limits of the Lv 1559 date when standard deviation is taken into account.

Two other dates were obtained from faunal material collected during the 1905 excavations. A set of bone splinters yielded a conventional date of 25,870 \pm 770 (Lv-720; Gilot, 1984) and an AMS date of $26,750 \pm 460 \mathrm{BP}$ (OxA-2452; Vrielynck, 1999) was obtained from a single fragment. These dates must be discarded for several reasons: unknown stratigraphic position of the specimens; uncertain stratigraphic association of the bone splinters; unclear relationship between the dates and the archaeological material; and convergence of dates (around 26,000) which is comparatively too recent for the lithic industry.

\section{Discussion and conclusion}

Before the present study, the Couvin $\mathrm{dm}_{2}$, supposedly associated with a transitional industry, was neither precisely described nor taxonomically attributed. Its chronological position was uncertain and the three available ${ }^{14} \mathrm{C}$ dates were deemed problematic.

The current anthropological study of the tooth concludes that the $\mathrm{dm}_{2}$ belongs to a Neandertal child. We suggest its occlusal morphology and enamel thickness are conclusive evidence of its taxonomic classification. 
The reconsideration of the Couvin lithic industry led us to question its homogeneity. Overall, the archaeological material found with the $\mathrm{dm}_{2}$ in 1984-1987 is similar to that from 1905. Consequently, the archaeologists who studied the lithic material during recent years had a tendency to associate the two collections (Cattelain et al., 1986; Ulrix-Closset et al., 1988; Ulrix-Closset, 1990; Otte, 1990; Flas, 2008). However, the 1905 material lacks any stratigraphic context as it comes from backfill. Whether the 1905 material was originally from a single layer or several layers cannot be demonstrated. In addition, the question of whether the 1905 material was from the same layer as the 1984-1987 material cannot be answered.

Independent arguments call for further caution in this matter. The faunal assemblage from the 1905 excavation appears very different when compared to the material from both the 1984-1987 and XIXth century excavations. Secondly, the two available ${ }^{14} \mathrm{C}$ dates from the 1905 material, both pointing to an age of c. 26,000 BP, are much younger than the two dates from the 1984-1987 material. Moreover, this age of 26,000 BP clearly does not fit with archaeological material dominated by sidescrapers. Finally, it is worth mentioning that technologically and typologically similar industries with similar raw material do not automatically represent a single archaeological occupation; such similarities can be found in markedly distinct stratigraphic layers covering a long chronological period, as illustrated by recent excavations at Walou Cave, near Liège (Draily, 2004).

For these reasons, the study of the industry associated with the Neandertal tooth must rely exclusively on lithic material collected during the 1984-1987 excavations. In addition, the 1984-1987 lithic artefacts as well as most of the faunal remains exhibit a vertical and horizontal distribution in layer II similar to that of the tooth (Fig. 7). Careful re-examination of this lithic material indicated a definite correspondence to the Middle Palaeolithic, with sidescrapers as the most prevalent artefact. Neither the few bifacial artefacts nor the few laminar flakes possess any diagnostic value and are therefore insufficient to consider the site industry as a transitional facies between the Middle and Upper Palaeolithic. This is also true of the 1905 material.

Re-examination of the stratigraphy adds new elements to these anthropological and archaeological conclusions, by revealing that layer III-above layer II in which the tooth was found-probably corresponds to an interstadial redish-brown palaeosol. According to the regional context, where similar pedological horizons were recorded in the Belgian loess belt as well as in Walou and Scladina caves, layer III should be dated, at the youngest, between 42,000 and $40,000 \mathrm{BP}$. Consequently, the archaeological occupation of the underlying layer II and the associated human tooth should be older. The two available radiocarbon dates directly associated with the tooth in layer II and obtained from faunal remains fully support this interpretation $(46,820 \pm 3,290 \mathrm{BP}$ and $44,500+1,100 /-800 \mathrm{BP})$. As the faunal assemblage from Trou de l'Abîme is most probably entirely of anthropic origin (cut marks, numerous burnt bones, absence of traces from carnivores), the radiocarbon results can be used to date the human occupation which should be situated around 46,000-44,000 BP, when taking the new AMS result into account. This chronological interval fully supports the attribution of the lithic material to the Middle Palaeolithic. On the contrary, according to the available chronological data for Northwestern Europe, this industry is older than the transitional industries such as Châtelperronian and Lincombian-Ranisian-Jerzmanowician and than the Early Upper Palaeolithic (e.g., Flas, 2008; Semal et al., 2009).

As far as calibration is concerned, for the period 26,000 to 45,000 cal BP most of the available records with ${ }^{14} \mathrm{C}$ data show strong deviations from each other, up to several millennia, preventing, at least up to now, any accurate calibration (van der Plicht et al., 2004). Despite recent progress, especially for dates younger than $40 \mathrm{ka}$ cal BP (ca. $35 \mathrm{ka}$ BP), some differences still exist, and therefore a true calibration curve is not yet available (Blockley et al., 2008). Since the two Couvin dates are largely older than $35 \mathrm{ka} \mathrm{BP}$ we did not attempt calibration.

Following our interpretation, the Couvin deciduous molar contributes only marginally to greater debates about the superseding of Neandertals by anatomically modern humans. With regard to this topic, the evidence presented here is only circumstantial, but supports the notion that just prior to $40,000 \mathrm{BP}$, northwestern Europe, and more specifically the Belgian Meuse Basin, was populated by Neandertals whose lithic tools were typical of the Middle Palaeolithic. Between 40,000 and 38,000 BP, this area was still occupied by Neandertals associated with a Late Middle Palaeolithic industry, as attested by the left lower Neandertal premolar found at Walou Cave in 1997, 105 km north-east of Trou de l'Abîme (Toussaint and Pirson, 2006). Later, around 36,000 BP, Neandertals were still present, as stated by recent ${ }^{14} \mathrm{C}$ dates of the Spy remains (Toussaint and Pirson, 2006; Semal et al., 2009). The absence of an accurate stratigraphic context for the Spy remains (due to the antiquity of the excavations) does not allow the determination of the archaeological industry which was associated with this population (i.e., either Late Middle Palaeolithic or LRJ transitional industry, both of which are present in Spy). However the hypothesis of the LRJ transitional facies seems to be the most probable according to the general northwestern European context where this industry is, so far, the only culture recognised around 36,000 BP.

In the case of many palaeoanthropological discoveries, especially the earlier ones, the stratigraphic context is inadequately known and contributes little to the discussion. This is probably one of the facts at the origin of numerous points of contention, notably regarding the passionate debate about the Middle to Upper Palaeolithic transition in Europe (Zilhão et al., 2008; versus Mellars and Gravina, 2008), in which the chronological data are mainly obtained from ${ }^{14} \mathrm{C}$ dates, with subsequent complications with calibration (e.g., van der Plicht et al., 2004) and pollution (e.g., Higham et al., 2006; Krause et al., 2007). In this context, new excavations associated with careful examination of the stratigraphy and of the sedimentary dynamics should provide important elements to these debates.

As far as Trou de l'Abîme is concerned, the potential of the site to yield more hominin remains might still be important. Test pit A, where the fossil was unearthed, was limited to a few square metres. At least a small area of undisturbed sediments appears to have been preserved at the north of it. The small degree of occlusal wear of the $\mathrm{dm}_{2}$ and the apparent destruction of its roots in situ suggest that the fossil was not lost during the normal process of eruption of the $\mathrm{P}_{4}$ but before it. So, barring an accident where the deciduous molar would have been lost prior to complete root resorption, the child probably passed away in the site or was brought to the site after death. Therefore, the deciduous molar was embedded in the mandible, which may still be present within the sediments, possibly with other parts of the skeleton. To explore such a possibility and in order to get additional information about the stratigraphy and palaeoenvironment of the deposits as well as to collect supplementary lithic and faunal materials, a new excavation is planned at Trou de l'Abîme in the near future by a joint team from the University of Liège and the Direction of Archaeology of the regional public service.

\section{Acknowledgements}

The authors wish to express their gratitude to Dr. Shara Bailey, palaeoanthropologist at New York University, for her precious advice on some anatomical details of the tooth; Dr. Tanya Smith, palaeoanthropologist at Harvard University, for insightful discussions on the dental age of the fossil; Prof. Dr. Eddy Poty, geologist at the University of Liège, who authorized the study of the Engis 2 
right $\mathrm{dm}_{2}$; Kevin Di Modica, archaeologist at the association "Archéologie andennaise" for discussions; Dr. Peter Ungar and Kristin Krueger for assisting in the collection of the dental microwear data; JHE editor Susan Antón and associate editor Debbie Guatelli-Steinberg, as well as Prof. Dr. Fred Smith and the anonymous reviewers for the thoughtful and constructive reviews of the manuscript; Sylviane Lambermont and Joel Eloy, graphic artists at the "Association wallonne d'Études mégalithiques"; Jean-François Lemaire, "Association wallonne d'Études mégalithiques," for different figures and correction of the English text. And finally, many thanks to Cheryl Roy, Malaspina University College, Nanaimo, $\mathrm{BC}$, Canada, and to Rebecca Miller, University of Liège, for taking the time to improve the English text.

\section{Supplementary data}

Supplementary data associated with this article can be found in the online version at doi:10.1016/j.jhevol.2009.09.006.

\section{References}

Bailey, S.E., 2002. Neandertal Dental Morphology: Implications for Modern Human Origins. Ph.D. dissertation, Arizona State University.

Bailey, S.E., Hublin, J.-J., 2006. Dental remains from the Grotte du Renne at Arcy-surCure (Yonne). J. Hum. Evol. 50, 485-508.

Blockley, S.P.E., Bronk Ramsey, C., Higham, T., 2008. The Middle to Upper Paleolithic transition: dating, stratigraphy, and isochronous markers. J. Hum. Evol. 55, 764771.

Bosinski, G., 2001. El Paleolítico medio en Europa central. Zephyrus 53-54, 79-142.

Campbell, J.B., 1986. Hiatus and continuity in the British Upper Palaeolithic: a view from the antipodes. In: Roe, D.A. (Ed.), Studies in the Upper Palaeolithic of Britain and Northwest Europe, 296. BAR International Series, Oxford, pp. 7-42.

Cattelain, P., Otte, M., Ulrix-Closset, M., 1986. Les cavernes de l'Abîme à Couvin. Notae Praehistoricae 6, 15-28.

Cordy, J.-M., 1984. Evolution des faunes quaternaires en Belgique. In: Cahen, D., Haesaerts, P. (Eds.), Peuples chasseurs de la Belgique préhistorique dans leur cadre naturel. Patrimoine de l'Institut royal des Sciences naturelles de Belgique, Brussels, pp. 67-77.

Defrise-Gussenhoven, E., 1955. Ellipses équiprobables et taux d'éloignement en biométrie. Bull. Inst. Roy. Sci. Nat. Belg. 26, 1-31.

Draily, C., 2004. Bilan des occupations moustériennes de la grotte Walou à Trooz (province de Liège, Belgique) et essai d'interprétation des couches à faible densité de matériel lithique. Notae Praehistoricae 24, 17-29.

El Zaatari, S., 2007. Ecogeographic Variation in Neandertal Dietary Habits: Evidence from Microwear Texture Analysis. Ph.D. dissertation, Stony Brook University.

Flas, D., 2008. La transition du Paléolithique moyen au supérieur dans la plaine septentrionale de l'Europe, Bruxelles. Anthropol. Praehist. 119, 254.

Gilot, E., 1984. Datations radiométriques. In: Cahen, D., Haesaerts, P. (Eds.), Peuples chasseurs de la Belgique préhistorique dans leur cadre naturel. Patrimoine de l'Institut royal des Sciences naturelles de Belgique, Brussels, pp. 115-125.

Grine, F., 1984. The Deciduous Dentition of the Kalahari San, the South African Negro and the South African Plio-Pleistocene Hominids. Ph.D. dissertation, University of the Witwatersrand.

Haesaerts, P., 2004. Maisières-Canal (2000-2002): cadre stratigraphique. In: Miller, R., Haesaerts, P., Otte, M. (Eds.), L'atelier de taille aurignacien de Maisières-Canal (Belgique), 110. Etudes et Recherches archéologiques de l'Université de Liège, Liège, pp. 13-26.

Haesaerts, P., Mestdagh, H., Bosquet, D., 1997. La séquence loessique de Remicourt (Hesbaye, Belgique). Notae Praehistoricae 17, 45-52.

Haesaerts, P., Teyssandier, N., 2003. The early Upper Paleolithic occupations of Willendorf II (Lower Austria): a contribution to the chronostratigraphic and cultural context of the beginning of the Upper Paleolithic in Central Europe. In: Zilhão, J., d'Errico, F. (Eds.), The Chronology of the Aurignacian and of the Transitional Technocomplexes. Dating, Stratigraphies, Cultural Implications. Proceedings of Symposium 6.I of the XIVth Congress of the UISPP, Liège, Belgium, September 2001. Trabalhos de Arqueologia 33, Lisboa, pp. 133-151.

Hammer, Ø., Harper, D.A.T., Ryan, P.D., 2001. PAST: paleontological statistics software package for education and data analysis. Available at: Palaeontol. Electr. 4 (1) http://palaeo-electronica.org/2001_1/past/issue1_01.htm.

Higham, T., Bronk Ramsey, C., Karavanić, I., Smith, F.H., Trinkaus, E., 2006. Revised direct radiocarbon dating of the Vindija $\mathrm{G}_{1}$ Upper Paleolithic Neandertals. Proc. Natl. Acad. Sci. 103, 553-557.

Jacobi, R., 2007. A collection of Early Upper Palaeolithic artefacts from Beedings, near Pulborough, West Sussex and the context of similar finds from British Isles. Proc. Prehist. Soc. 73, 229-325.

Jöris, O., 2003. Zur chronostratigraphischen Stellung der spätmittelpaläolithischen Keilmessergruppen. Der Versuch einer kulturgeographischen Abgrenzung einer mittelpaläolithischen Formengruppe und ihr europäischer Kontext. Ber. Römisch-Germanischen Kommission 84, 49-153.

Kono, R., 2004. Molar enamel thickness and distribution patterns in extant great apes and humans: new insights based on a 3-dimensional whole crown perspective. Anthropol. Sci. 112, 121-146.

Krause, J., Orlando, L., Serre, D., Viola, B., Prüfer, K., Richards, M.P., Hublin, J.-J. Hänni, C., Derevianko, A.P., Pääbo, S., 2007. Neanderthals in central Asia and Siberia. Nature 449, 902-904.

de Loë, E., 1906. Fouilles dans la terrasse du "Trou de l'Abîme" à Couvin (prov. de Namur). Bull. Mus. Roy. Arts Décoratifs et Industriels VI, 6-7.

Lohest, M., Braconier, J., 1887-1888. Exploration du Trou de l'Abîme à Couvin. Annls. Soc. Géol. Belg. 15, LXI-LXVII.

Macchiarelli, R., Bondioli, L., Debećnath, A., Mazurier, A., Tournepiche, J.-F., Birch, W., Dean, C., 2006. How Neanderthal molar teeth grew. Nature 444, 748-751.

Maillieux, E., 1903. Fouilles au Trou de l'Abîme. Bulletin de la Société belge de Géologie 17, 583-585.

Mellars, P., Gravina, B., 2008. Châtelperron: theoretical agendas, archaeological facts, and diversionary smoke-screens. PaleoAnthropology, 4-64.

Molnar, S., 1971. Human tooth wear, tooth function and cultural variability. Am. J. Phys. Anthropol. 34, 175-190.

Olejniczak, A.J., 2006. Micro-computed Tomography of Primate Molars. Ph.D dissertation, Stony Brook University.

Olejniczak, A.J., Grine, F.E., 2005. High-resolution measurement of Neandertal tooth enamel thickness by micro-focal computed tomography. S. Afr. J. Sci. 101, 219-220.

Olejniczak, A.J., Smith, T.M., Feeney, R.N.M., Macchiarelli, R., Mazurier, A., Bondioli, L., Rosas, A., Fortea, J., de la Rasilla, M., Garcia-Tabernero, A., Radovčić, J. Skinner, M.M., Toussaint, M., Hublin, J.-J., 2008. Molar tissue proportions and enamel thickness distinguish Neandertals from modern humans. J. Hum. Evol. $55,12-23$.

Otte, M., 1984. Le Paléolithique supérieur en Belgique. In: Cahen, D., Haesaerts, P. (Eds.), Peuples chasseurs de la Belgique préhistorique dans leur cadre naturel. Patrimoine de l'Institut royal des Sciences naturelles de Belgique, Brussels, pp. 157-179.

Otte, M., 1990. From the Middle to the Upper Palaeolithic: the nature of the transition. In: Mellars, P. (Ed.), The Emergence of Modern Humans. An Archaeological Perspective. Edinburgh University Press, Edinburgh, pp. 438-456.

Pirson, S., 2007. Contribution à l'étude des dépôts d'entrée de grotte en Belgique au Pléistocène supérieur. Stratigraphie, sédimentologie et paléoenvironnement. Ph.D. dissertation, University of Liège.

Pirson, S., Court-Picon, M., Haesaerts, P., Bonjean, D., Damblon, F., 2008. New data on geology, anthracology and palynology from the Scladina Cave pleistocene sequence: preliminary results. Bruxelles, Memoirs of the Geological Survey of Belgium 55, 71-93.

Pirson, S., Haesaerts, P., Court-Picon, M., Damblon, F., Toussaint, M., Debenham, N.C. Draily, C., 2006. Belgian cave entrance and rock-shelter sequences as palaeoenvironmental data recorders: the example of Walou cave. Geologica Belgica 9, 275-286.

van der Plicht, J., Beck, J.W., Bard, E., Baillie, M.G.L., Blackwell, P.G., Buck, C.E., Friedrich, M., Guilderson, T.P., Hughen, K.A., Kromer, B., McCormac, F.G., Bronk Ramsey, C., Reimer, P.J., Reimer, R.W., Remmele, S., Richards, D.A., Southon, J.R. Stuiver, M., Weyhenmeyer, C.E., 2004. NOTCAL04-Comparison/Calibration ${ }^{14} \mathrm{C}$ records 26-50 cal kyr BP. Radiocarbon 46 (3), 1225-1238.

Révillion, S., Tuffreau, A. (Eds.), 1994. Les industries laminaires au Paléolithique moyen. CNRS éditions, Paris.

Schwartz, G.T., 2000. Taxonomic and functional aspects of enamel thickness distribution in extant large-bodied hominoids. Am. J. Phys. Anthropol. 111 $221-244$

Scott, G.R., Turner II, C.G., 1997. The Anthropology of Modern Human Teeth. Dental Morphology and Its Variations in Recent Human Populations. Cambridge University Press, Cambridge.

Scott, R.S., Ungar, P.S., Bergstrom, T.S., Brown, C.A., Childs, B.E., Teaford, M.F Walker, A., 2006. Dental microwear structure analysis: technical considerations. J. Hum. Evol. 51, 339-349.

Semal, P., Rougier, H., Crevecoeur, I., Jungels, C., Flas, D., Hauzeur, A., Bocherens, H., Cammaert, L., De Clerck, N., Germonpré, M., Hambucken, A., Higham, T., Maureille, B., Pirson, S., Toussaint, M., van der Plicht, J., 2009. Direct AMS ${ }^{14} \mathrm{C}$ dating of the Spy I and Spy II adult Neandertals (Belgium): implication about recent Neandertal settlement in North-West Europe. Am. J. Phys. Anthropol. $138,421-428$.

Slimak, L., 2008. Circulations de matériaux très exotiques au Paléolithique moyen, une notion de détail. Bull. Soc. Préhist. Fr. 105 (2), 267-281.

Slimak, L., Lucas, G., 2005. Le débitage lamellaire, une invention aurignacienne? In: Le Brun-Ricalens, F., Bordes, J.-G., Bon, F. (Eds.), Productions lamellaires attribuées à l'Aurignacien. Chaînes opératoires et perspectives technoculturelles, ArchéoLogiques 1 Actes du XIV ${ }^{\mathrm{e}}$ congrès UISPP, Luxembourg, pp. 75-100 (Liège, September 2001)

Smith, P., Zilberman, U., 1994. Thin enamel and other tooth components in Neanderthals and other hominids. Am. J. Phys. Anthropol. 95, 85-87.

Tafforeau, P., 2004. Aspects phylogénétiques et fonctionnels de la microstructure de l'émail dentaire et de la structure tridimensionnelle des molaires chez les primates fossiles et actuels: apports de la microtomographie à rayonnement $\mathrm{X}$ synchrotron. Ph.D. dissertation, University of Montpellier II.

Teaford, M.F., Oyen, O.J., 1989. Live primates and dental replication: new problems and new techniques. Am. J. Phys. Anthropol. 80, 73-81. 
Tillier, A.-M., 1990. Néanderthaliens et origine de l'homme moderne en Europe: quelques réflexions sur la controverse. In: Paléolithique moyen récent et Paléolithique supérieur ancien en Europe, 3. Mémoires du Musée de Préhistoire d'Ile-de-France, pp. 21-24.

Toussaint, M., Pirson, S., 2006. Neandertal studies in Belgium: 2000-2005. Period. Biol. 108 ( $\left.n^{\circ} 3\right)$, 373-387.

Trinkaus, E., 2007. European early modern humans and the fate of the Neandertals. Proc. Natl. Acad. Sci. 104, 7367-7372.

Turner II, C.G., Nichol, C.R., Scott, G.R., 1991. Scoring procedures for key morphological traits of the permanent dentition: the Arizona State University Denta Anthropology System. In: Kelley, M., Larsen, C. (Eds.), Advances in Dental Anthropology. Liss, New York, pp. 13-31.

Ulrix-Closset, M., 1990. Le paléolithique moyen récent en BelgiquePaléolithique moyen récent et Paléolithique supérieur ancien en Europe. Colloque international de Nemours, 9-11 mai 1988. Mémoires du Musée de Préhistoire d'Ile-de-France 3, 135-143.

Ulrix-Closset, M., Otte, M., Cattelain, P., 1988. Le "Trou de l'Abîme" à Couvin (Province de Namur, Belgique). In: L'Homme de Néandertal. La mutation, vol. 8. Etudes et Recherches archéologiques de l'Université de Liège 35, Liège, pp. 225-239.

Vrielynck, O., 1999. La chronologie de la préhistoire en Belgique. Inventaire des datations absolues, 8 . Société wallonne de Palethnologie.

Weidenreich, F., 1937. The dentition of Sinanthropus pekenensis: a comparative odontography of the hominids. Paleontol. Sin. whole series 101, new series D-1, Peking.

Zilhão, J., d'Errico, F., Bordes, J.-G., Lenoble, A., Texier, J.-P., Rigaud, J.-P., 2008. Grotte des Fées (Châtelperron): history of research, stratigraphy, dating, and archaeology of the Châtelperronian type-Site. PaleoAnthropology, 1-42. 